\title{
Evaluation of haemato-biochemical changes, oxidative stress response and stress related gene expressions in juvenile Labeo rohita (Hamilton, 1822) in response to Mycobacterium fortuitum infection
}

\author{
PARIJAT DAS, TIRTHANKAR SAHA AND TAPTI SENGUPTA \\ Department of Microbiology, West Bengal State University, Berunanpukuria, Malikapur, Barasat, North 24 parganas \\ Kolkata - 700 126, West Bengal, India \\ e-mail: tapti.sg@gmail.com
}

\begin{abstract}
Non-tuberculous mycobacteria present in aquaculture systems can infect and influence the physio-chemical blood parameters of captive fish. The aim of this study was to examine the changes in haematological and biochemical parameters along with expression of stress related genes in response to Mycobacterium fortuitum infection in the Indian major carp, rohu Labeo rohita (Hamilton, 1822). Juveniles of L. rohita were experimentally infected with M. fortuitum strain ATCC 6841, by immersion challenge at three different dosages of $5 \times 10^{5} \mathrm{cfu} \mathrm{fish}^{-1}\left(\right.$ group $\mathrm{T}_{2}$ ), $5 \times 10^{6} \mathrm{cfu} \mathrm{fish}^{-1}$ (group $\mathrm{T}_{3}$ ) and $5 \times 10^{7} \mathrm{cfu} \mathrm{fish}^{-1}$ (group $\mathrm{T}_{4}$ ) along with a control group. After 60 days post-infection, fishes in groups $\mathrm{T}_{2}, \mathrm{~T}_{3}$ and $\mathrm{T}_{4}$ were observed with necrotic lesions in skin and M. fortuitum was recovered from moribund fishes. Heat shock protein $(h s p)$ gene expression analysis was performed in liver tissues by RT-PCR and $h s p$ s were analysed by Western Blotting in fishes of all treatment groups and control. Significant changes $(\mathrm{p}<0.05)$ were found in haemato-biochemical parameters including glucose, cortisol, blood parameters, liver enzymes, serum proteins and catalase and superoxidase dismutase activity along with mRNA expression of $h s p$ genes viz, $h s p 60, h s p 70, h s p 78, h s p 90$ and $h s p 47$ within groups $\mathrm{T}_{3}$ and $\mathrm{T}_{4}$ in comparison to control. The results suggest the pathogenicity of $M$. fortuitum (ATCC 6841) to L. rohita by promoting stress parameters and the transcription level of stress related genes.
\end{abstract}

Keywords: Fish tuberculosis, Heat shock protein, Mycobacterium fortuitum, Mycobacteriosis, Rohu

\section{Introduction}

Mycobacterium fortuitum was categorised as a rapid growing mycobacterium (Katoch, 2004; Parashar et al., 2004) which is often associated with tubercle granulomas in fish of fresh, brackish and marine aquaculture. This species of Mycobacterium is frequently isolated from various sources in both temperate and tropical environment (Collins et al., 1984; Prearo et al., 2004). Bacteria under genus Mycobacterium are environmental saprophytes, Gram positive, acid-fast, non-motile, aerobic rods under the order Actinimycetales and family Mycobacteriaceae (Smole et al., 2002). Initially it was isolated from animal sample in 1978 (Wilkinson et al., 1978) and further implicated as animal and human pathogen (Brown, 1985). Pathogenicity of chronic mycobacteriosis due to M. fortuitum invasion has been evaluated using goldfish (Carassius auratus) as laboratory animal (Talaat et al., 1998; 1999). This pathogen penetrates through the oral route or injured skin (Noga et al., 1990) and eventually forms a chronic progressive disease by invading the visceral organs like hepato-intestinal system (Astrofsky et al., 2000; Rhodes et al., 2004; Marzouk et al., 2009). Fishes may develop various clinical features ranging from small nodules to wide ulcerations, rupture in the skin and underneath muscles, fin damage, pigment alteration, spinal curvature with loss of appetite, impairment in growth and lethargy (Balouet and Baudin, 1986; Heckert et al., 2001). M. fortuitum has also been recognised in cases of cattle and sheep mastitis, pulmonary and subcutaneous abscesses (Fox et al., 1995), cutaneous granulomatous and neurological disorder in rare cases (Saito and Tasaka, 1969). Severe outbreak of chronic infections can adversely alter the haemato-biochemical, histopathological and different physiological stress parameters which ultimately lead to mortality in fish.

Intensive aquaculture has rapidly expanded in the eastern zones of India where culture practice of carps comprises about $87 \%$ of total freshwater fish farms. The rohu, Labeo rohita (Hamilton, 1822) is the most dominant Indian major carp (IMC) species due to their high commercial value, satisfactory growth rate and consumer acceptability (Prasad et al., 2012). In aquaculture, various environmental and chemical stressors, crowding and poor nutrition can deteriorate the immune systems of carps making them vulnerable to a variety of environmental pathogens. Water borne mycobacterial pathogens are 
often opportunistic to immunocompromised fishes and are regarded as one of the major threats for aquatic animals (Shukla et al., 2013). M. fortuitum, M. marinum, $M$. chelonae and $M$. phlei are the most common mycobacterial species that have been recognised as causative agents of mycobacteriosis in aquatic animals (Bercovier and Vincent 2001; Heckert et al., 2001; Sanders and Swaim, 2001).

Epidemiology of mycobacterial fish pathogens need to be well understood for facilitating prevention and for adopting treatment strategies. In recent decades, studies on non-specific immunity and stress related aspects in host pathogen interaction in fishes is growing surprisingly, as the components of innate immune systems including a class of cytokines, complement factors and their relevant gene expression has vital role in evaluation of fish immune modulation (Zhu et al., 2013). In addition, a class of heat shock proteins ( $h s p s$ ) or stress proteins are found to influence both innate and adaptive immune response and are known to be associated with protein folding, protein transporting and reconstruction, macromolecular domain assembly with various ways of inflammatory responses (Srivastava 2002; Kakkar et al., 2014). Thus, assessing the level of $h s p$ gene expressions can be a commendable approach to comprehend the physiological stress and immunogenic response in both laboratory and naturally grown fish species (Purohit et al., 2014).

M. fortuitum infections may induce considerable stress levels in IMCs which are economically most important for the aquaculture sector. Unfortunately, no effective treatment has been established against M. fortuitum infections in fish. The present study was undertaken to understand the relevant pathology of $M$. fortuitum with the analysis of haematological and serum biochemical changes in blood, the oxidative stress response and expression of the heat shock protein ( $h s p)$ genes provoked by experimentally induced $M$. fortuitum infection in L. rohita. The study involved assessment of haematological changes, serum metabolic parameters, stress hormone and crucial liver enzymes of $L$. rohita. The expression level of stress genes viz, hsp60, hsp70, hsp 78, $h s p 90$ and $h s p 47$ of hepatic cell and immune-blot analysis of $h s p 60, h s p 70$ and $h s p 90$ were also carried out.

\section{Materials and methods}

\section{Bacterial culture and growth conditions}

Mycobacterium fortuitum ATCC 6841 (www.atcc. org.) was grown in Middlebrook 7H9 broth (HiMedia, India) supplemented with $10 \%$ oleic acid, albumin, dextrose and catalase (OADC) at $37^{\circ} \mathrm{C}$ and incubated for seven days. Bacterial suspension was acquired from the mid-exponential growth phase and centrifuged at $4000 \mathrm{~g}$ for $10 \mathrm{~min}$, re-suspended in phosphate buffered saline $(\mathrm{pH} 7.4)$ and adjusted to a concentration of $5 \times 10^{5} \mathrm{cfu} \mathrm{ml}^{-1}$. Final bacterial concentration was confirmed by serial dilutions and plating (Talaat et al., 1998).

\section{Experimental fishes and treatments}

The experiment was conducted with 120 numbers of healthy juvenile L. rohita $(15 \pm 3 \mathrm{~cm})$ weighing between 235.0-250.0 g, procured from a local fish farm in West Bengal, India. Fishes were left undisturbed and maintained in static re-circulating water $\left(27^{\circ} \mathrm{C}\right)$ overnight and were given a mild $\mathrm{NaCl}(2 \%)$ treatment for $2 \mathrm{~min}$ in the next day morning. To ameliorate the stress created by transportation, fishes were also given a bath treatment of vitamin $\mathrm{C}\left(2 \mathrm{mg} \mathrm{l}^{-1}\right)$ and were acclimatised under aerated conditions for 15 days. Fishes were fed on a formulated fish diet containing Danish fish meal (70\%), wheat flour $(12 \%)$, soybean lecithin $(5 \%)$, cod liver oil $(5 \%)$, vitamin premix $(3 \%)$, mineral premix (3\%) and carboxyl methyl cellulose $(2 \%)$. Apparently healthy fishes free of fungal, parasitic or bacterial infections were selected prior to distribution for experimental trial.

Each fish tank ( $80 \times 58 \times 40 \mathrm{~cm}, 150$ 1) was disinfected with $\mathrm{KMnO}_{4}$ solution $\left(4 \mathrm{mg} \mathrm{l}^{-1}\right)$ before distribution of fish. Total 120 fishes were randomly distributed in 1 control and 3 experimental groups, each with three replicates (10 fish $\mathrm{x} 3$ tank $=30$ fishes in each group). After distribution, the fishes were acclimatised with a photoperiod of $14 \mathrm{~h}$ light and $10 \mathrm{~h}$ darkness for 2 weeks prior to the experiment. Group 1 marked as control and treatment groups 2, 3 and 4 were marked as $\mathrm{T}_{2}, \mathrm{~T}_{3}$ and $\mathrm{T}_{4}$ respectively. Stock bacterial dilutions (M. fortuitum ATCC 6841) of $5 \times 10^{6} \mathrm{cfu} \mathrm{m}^{-1}$,

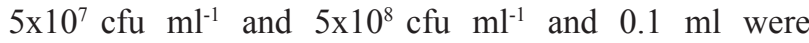
used for injection to each fish, thus the final injection doses used were: $5 \times 10^{5} \mathrm{cfu} \mathrm{fish}^{-1}, 5 \times 10^{6} \mathrm{cfu}^{\mathrm{fish}}{ }^{-1}$ and $5 \times 10^{7}$ cfu fish $^{-1}$ in group $\mathrm{T}_{2}, \mathrm{~T}_{3}$ and $\mathrm{T}_{4}$ respectively. Fishes were subjected to cold shock by adding ice cubes for temporary anesthesia while injecting intra-peritoneally. The fishes were fed with same protein rich diet up to their level of satiation throughout the 60 days of experimental period.

\section{Weight parameters and survival rate}

Fishes in each treatment group were found to reduce weight post-infection; might be caused due to reduced food intake followed by bacterial inflammation and hence weight reduction parameter was considered. The initial and the final biomass weight of all experimental fishes was assessed and weight reduction was calculated using the formula:

Weight gain/reduction $(\%)=[($ Initial weight - Final weight) / Final weight] x 100

At the end of the experiment, all the fish tanks were dewatered and the number of experimental fishes in each 
tank was counted and the survival rate was calculated using the formula:

Survival rate $(\%)=($ Total number of fish alive at end of experiment / Total number of fish stocked) x 100

Collection of blood and serum sample

Ten fishes from each group (30 per group) were sampled and a total of 120 fishes were sampled on days 30 and 60 for blood and serum collection. Fishes were anesthetised by cold shock using ice one at a time in a separate sterile container. Blood was collected from caudal peduncle with a tuberculin syringe rinsed with $2.7 \%$ EDTA solution and transferred to sterile tube rinsed with EDTA, at $4^{\circ} \mathrm{C}$ for analysis of blood glucose level, haemoglobin content, total erythrocyte count and lymphocyte count. For collection of serum (from the same fish), blood was allowed to clot in micro-centrifuge tubes by leaving it undisturbed at room temperature for $15 \mathrm{~min}$ and centrifuged at $4000 \mathrm{~g}$ for $3 \mathrm{~min}$. Supernatant was collected in micro-centrifuge tubes and stored at $-20^{\circ} \mathrm{C}$ for analysis of serum cortisol, serum total proteins, albumin globulin ratio, liver enzymes and serum catalase and superoxidase dismutase activity.

Histopathological examination and recovery of Mycobacterium from tissue

At the end of the experimental period (60 days), fishes were sacrificed to collect liver and kidney tissues for histopathological analyses. The tissues were kept in $10 \%$ neutral buffered formalin for $10 \mathrm{~min}$, washed with running tap water and dehydrated with $90 \%$ ethanol followed by embedding in paraffin block. A $5 \mu \mathrm{m}$ section of paraffin embedded tissues were cut using rotary microtome and stained with haematoxylin and eosin (Gail et al., 1996). Degree of infection was analysed depending on microscopic pathology of stained slide and the tissues were graded based on granuloma score (GS) (Reimschuessel et al., 1992), that described the score of 0 as normal, 1-2 as minimal, 3-4 as mild, 5-6 as moderate, 7-8 as severe and 9-10 as highly severe state of granuloma. Cumulative granuloma score (CGS) was calculated as sum of GS of infected organs in a fish. The mean cumulative granuloma score (MCGS) of each treatment group was also measured (Reimschuessel et al., 1992; Talaat et al., 1999). Skin scrapings were aseptically collected and immersed in $70 \%$ alcohol followed by $90 \%$ alcohol for $10 \mathrm{~min}$ and $5 \mathrm{~min}$ respectively and stained according to Ziehl-Neelsen method to detect acid fast bacilli. Skin, liver and peritoneal tissues weighing $100 \mathrm{mg}$ were taken under sterile conditions and homogenised with $2 \mathrm{ml}$ of PBS and $0.5 \mathrm{ml}$ of $2 \%$ glycerol. Tissue suspension $(1 \mathrm{ml})$ was decontaminated with $0.5 \mathrm{ml}$ of $2 \% \mathrm{HCl}$ and washed with $2 \mathrm{ml}$ of PBS. The final suspension was poured in
Lowenstein-Jensen (L-J) medium slant and incubated at $37^{\circ} \mathrm{C}$. After 7 days post-incubation, dry and rough pale-yellow colonies developed were subjected to Ziehl-Neelsen staining and PCR amplification for confirmation as M. fortuitum (Shukla et al., 2013).

\section{Estimation of blood glucose and serum cortisol}

Blood glucose was estimated by modified Nelson and Somogyi method (Oser, 1944). For estimation of blood glucose, $100 \mu \mathrm{l}$ of blood sample was de-proteinised by treating with a mixture of $4.5 \mathrm{ml}(0.174 \mathrm{M})$ of zinc sulphate and $4.5 \mathrm{ml}(0.142 \mathrm{M})$ of barium hydroxide solution. The whole mixture was filtered and $0.5 \mathrm{ml}$ filtrate was collected in a sterile test tube, mixed with $1 \mathrm{ml}$ of alkaline copper sulphate solution, placed in boiling water bath for $15 \mathrm{~min}$, cooled to room temperature and then $1 \mathrm{ml}$ of arseno-molybdate reagent was added. The absorbance was measured at $540 \mathrm{~nm}$ against blank. Serum cortisol was estimated by cortisol test EIA kit employing AccuBind Elisa Micro wells (Monobind Inc.) with microplate reader (Halo MPR-96 Dynamica).

\section{Haematological parameters}

Estimation of haemoglobin $(\mathrm{Hb})$ was performed using cyanmethaemogobin method. About $5 \mathrm{ml}$ of Drabkin's solution was mixed with $20 \mu \mathrm{l}$ of blood in a dry test tube and absorbance was measured in a spectrophotometer (Systronics 2202) at $540 \mathrm{~nm}$. Measurements of total erythrocyte count (TEC) and total leukocyte count (TLC) was done using haemocytometer by taking $3.98 \mathrm{ml}$ of erythrocyte and leukocyte diluting fluids (Qualigens) respectively in separate glass vials and $20 \mu$ l of blood was added to each vial to get a cell suspension and the cells were counted in haemocytometer to calculate TEC and TLC using the formula:

Number of cells $\mathrm{ml}=($ Number of cell counted $\times$ dilution) / (Area counted $\times$ depth of fluid).

\section{Serum total protein, albumin and globulin}

Biuret method was followed to estimate the serum total protein using Innoline total protein kit (Reinhold, 1953). Serum albumin was estimated using Innoline albumin kit following bromocresol green binding method (Doumas and Biggs, 1972). Absorbance of the standard and tests were measured at $550 \mathrm{~nm}$ and $578 \mathrm{~nm}$ respectively for total serum protein and albumin. Serum globulin content was obtained by subtracting the albumin value from total protein value.

\section{Analysis of enzymes}

Serum alanine aminotransferase (ALT) (Pathozyme Diagnostics), aspertate aminotransferase (AST) (Pathozyme Diagnostics), lactate dehydrogenase (LDH) 
(Pathozyme Diagnostics) and alkaline phosphatase (ALP) (CoralClinical Systems) were estimated by respective enzyme kinetic assay kits. Serum superoxidase dismutase (SOD) activity was measured (Sun et al., 2010) using nitroblue tetrazolium (NBT, HiMedia, India) at room temperature. One unit of superoxide dismutase was defined as the amount of enzyme that can cause 50\% inhibition in NBT reduction rate. The OD of supernatant was estimated at $550 \mathrm{~nm}$ in microplate reader (Infinite M200 PRO). Catalase activity was estimated (Takahara et al., 1960) as unit of catalase activity i,e., the amount of enzyme necessary to decompose $1 \mu \mathrm{M}$ of $\mathrm{H}_{2} \mathrm{O}_{2}$ per minute.

Extraction of RNA and expression of heat shock protein gene

For gene expression analysis, liver tissue was collected at the end of the 60 days of experimental period and immediately transferred to RNALater (Sigma) at $-20^{\circ} \mathrm{C}$ for further use. Total RNA was extracted from the liver sample using RiboZol (HiMedia, India) according to the manufactures protocol. Concentration of RNA was assessed by electrophoresis using agarose-formaldehyde gel (1\% agarose, 16\% formaldehyde) and measured by UV spectrophotometer (Systronics 2202). All extracted RNA samples showed A260/A280 ratio of 1.8-2.0. Extracted RNA $(1 \mu \mathrm{g})$ was reverse transcribed into cDNA using MMuLV reverse transcriptase (Fermentas) as per manufacturer's instructions. cDNA samples were kept at $-20^{\circ} \mathrm{C}$ until qPCR was performed. The PCR amplification of $h s p 60, h s p 70, h s p 90, h s p 78$ and $h s p 47$ genes ware performed using respective primers (Table 1) and Beta-actin was used as the housekeeping gene (Mohanty et al., 2010). Each $20 \mu \mathrm{l}$ of reaction mixture contained SYBR Green PCR Master Mix (Bio-Rad, UK), 2 l (200 ng) of synthesised cDNA, $1 \mu \mathrm{l}(0.2 \mu \mathrm{m})$ of each forward and reverse primer and molecular grade water. Reaction was performed in a CFX connect real time PCR detection system (Bio-Rad, UK). The cycling patterns were started with an initial denaturation of $3 \mathrm{~min}$ at $95^{\circ} \mathrm{C}$, followed by 40 cycles each of: denaturation for $10 \mathrm{~s}$ at $95^{\circ} \mathrm{C}$, followed by $30 \mathrm{~s}$ at standardised annealing temperature for specific genes (Purohit et al., 2014) and a final extension for 30 $\mathrm{S}$ at $72^{\circ} \mathrm{C}$. Each sample was analysed in three replicates. At the end of the reactions, $10 \mu \mathrm{l}$ of PCR products were visualised in $1.6 \%$ agarose gel. Relative fold expression of each $h s p$ was recorded against basal level of expression (control) with Bio-Rad Gel doc XR+ with image lab software.

\section{Extraction of protein and Western blotting (1D)}

Frozen liver samples were homogenised in ice-cold PBS (0.01 M, pH 7.4) containing protease Inhibitor (Sigma). The homogenate was centrifuged at $11500 \mathrm{~g}$ at $4^{\circ} \mathrm{C}$ for $15 \mathrm{~min}$ and the supernatant was stored at $-20^{\circ} \mathrm{C}$ until analysis. Liver proteins from supernatant were separated by SDS-PAGE using Mini-PROTEAN 3 Cell (Bio-Rad). 1-DImmune-blot assay were performed to analyse the stress protein expression from liver. An iBlot transfer system (Invitrogen) was used to transfer the proteins from poly-acrylamide gels to nitrocellulose (NC) membranes $(0.2 \mu \mathrm{m}$, Sigma). Transferring procedure was confirmed by staining a piece of nitrocellulose membrane with Ponceau S (Sigma). Primary antibodies were anti heat shock protein 60 (Sigma) anti heat shock protein 70 (Sigma) and anti heat shock 90 (Sigma) while secondary antibody used was anti mouse IgG-peroxidase conjugate (Sigma). DAB (3, 3'-Diaminobenzidine) (Sigma) and $\mathrm{H}_{2} \mathrm{O}_{2}$ were used as substrates (Mohanty et al., 2010).

\section{Statistical analysis}

Data of serum biochemical parameters were subjected to one-way analysis of variance (ANOVA) using software package SPSS (Version 18.0 for Windows; SPSS Inc, IL, USA). Differences among means of different groups were

Table 1. Primer sets used (Purohit et al., 2014) for quantitative RT-PCR analysis of hsp genes in L. rohita

\begin{tabular}{lllll}
\hline Target gene & Primer & Sequence (5'-3') & Amplicon size (bp) & Annealing temperature \\
\hline hsp60 & hsp60 F & TCGCACTGTCATCATTGAGC & 91 & $60^{\circ} \mathrm{C}$ \\
& hsp60 R & CTTGTCTTTCAGGTCGATGG & & $57^{\circ} \mathrm{C}$ \\
\hline hsp70 & hsp70 F & GTCGTCGATCTGTCCCTTGT & 98 & \\
& hsp70 R & CTCGCTTTGAGGAGCTGTG & & $60^{\circ} \mathrm{C}$ \\
\hline hsp78 & hsp78 F & GTCTTGGTGGGTGGCTCTAC & 94 & $60^{\circ} \mathrm{C}$ \\
& hsp78 R & TCAGGGTTGATGCCCCTAGA & & $52^{\circ} \mathrm{C}$ \\
\hline hsp90 & hsp90 F & CTGGGGTCTGTCAAGCTTTC & 122 & $62^{\circ} \mathrm{C}$ \\
& hsp90 R & AGGCCTTGGACAAAATCAGA & & \\
\hline Bsp47 & Hsp47 F & CTGACAGAGGCTGTGGACAA & 60 & \\
& Hsp47 R & GTCCTTCTTCCCGGAGATGT & & \\
\hline
\end{tabular}

F- Forward; R-Reverse 
compared by Duncan's multiple range test, where level of significance was explained as $p<0.05$. Results were presented as Mean \pm Standard error. The gene expression levels were graphically presented using GraphPad Prism version 6 (GraphPad Prism Software Inc.).

\section{Results}

Clinical signs, cumulative granuloma scores and recovery of acid-fast bacilli from tissues

Noticeable clinical signs started appearing at the $5^{\text {th }}$ week post-inoculation including inappetence, exophthalmia and distended abdomen with discolouration of scales, reddish tints to skin, gills and fins as well as nodular ulceration with haemorrhagic secretion. Acid fast rods were identified from skin scrapingss from infected tissues (Fig. 1a). Pathomorphological patterns were roughly similar in group $\mathrm{T}_{3}$ and $\mathrm{T}_{4}$ by 60 days post-inoculation. Percentage of weight reduction was significantly $(p<0.01)$ different among various treatment groups when compared to the control (Table 2). Maximum reduction of weight was found in group inoculated with $5 \times 10^{8} \mathrm{CFU} \mathrm{ml}{ }^{-1}$ of bacterial suspension $\left(\mathrm{T}_{4}\right)$ when compared to other groups. No mortality was recorded among control and all treatment groups during experimental period.
Histopathological examination showed severe and moderate granulomatous lesions in group $\mathrm{T}_{3}$ and $\mathrm{T}_{4}$ respectively (Table 2). Internal granulomas in fishes were characterised by accumulation of macrophages, lymphocytes, fibrocytes, epithelioid tissues and fibrous connective tissue especially around liver (Fig. 1c) and necrotic kidney (Fig. 1e). Ziehl-Neelsen staining of intestinal swab of fishes of group $\mathrm{T}_{3}$ showed presence of acid fast bacilli embedded in necrotic tissue (Fig. 1b). Acid fast rods were identified in liver section of infected fish that explained the occurrence of leukocyte and macrophage infiltration, erythematous hepatitis and dilated sinusoids. Cytoplasmic vacuolisation were observed in hepatic epithelial cells in group $\mathrm{T}_{3}$ and $\mathrm{T}_{4}$ (Fig. 1d). The overall mean cumulative granuloma score (MCGS) was significantly higher in group $\mathrm{T}_{4}(\mathrm{p}<0.01)$ followed by $\mathrm{T}_{3}$ and $\mathrm{T}_{2}$ in comparison to control (Table 2). Mycobacterium was recovered from parenchymal tissues of sacrificed fishes of the three experimental groups (Fig. 1). Colonies were confirmed as acid-fast positive by Z-N staining method which were finally confirmed as Mycobacteriam fortuitum through 16Sr-DNA gene amplification. No mortality was recorded in all treatment groups including control at the end of the experiment. Fishes in control group were clinically and histopathologically normal.

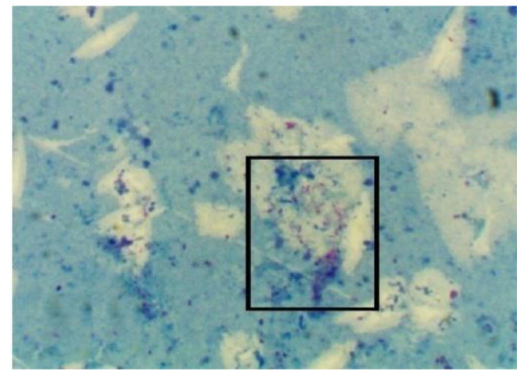

(a)

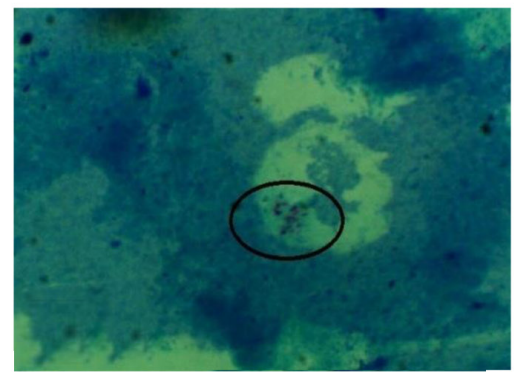

(b)

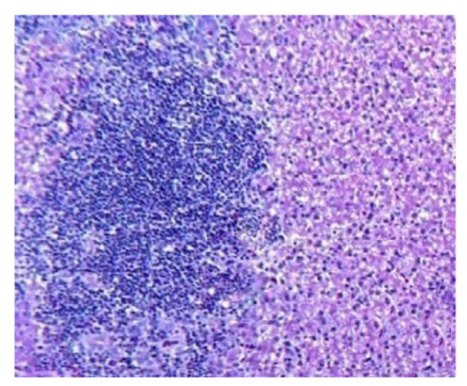

(c)

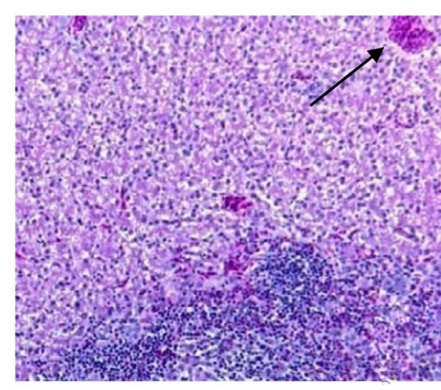

(d)

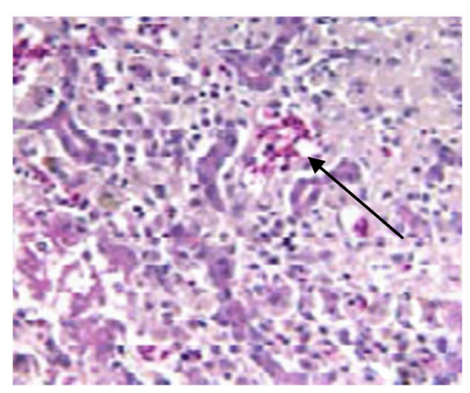

(e)

Fig. 1. (a). Large number of acid-fast positive bacilli in necrotic skin tissues taken from ulceration site of L. rohita from group $\mathrm{T}_{4}$; (b) Ziehl-Neelsen staining of infected intestinal swab showing acid fast bacilli embedded in necrotic tissues taken from group $\mathrm{T}_{3}$; (c) Histological examination of fish liver from control group showed score: ' 0 ' as absence of lesions; (d) Histopathological analysis of liver sample from the fish of group $\mathrm{T}_{4}$ had score ' 5 ' as moderate lesions showing the formation of focal granuloma due to accumulation of acid fast bacilli associated with infiltration of lymphocytes within tissue; (e) Outsized number of acid fast positive bacilli were visible in necrotic kidney in fish of group $\mathrm{T}_{4}$ showing score ' 7 ' as severe lesions. 
Table 2. Degree of infections in different groups of experimental fishes

\begin{tabular}{llllllll}
\hline Treatment group & $\begin{array}{l}\text { No. of fish } \\
\text { inoculated }^{\mathrm{a}}\end{array}$ & $\begin{array}{l}\text { No. of fish } \\
\text { examined fish }^{\mathrm{b}}\end{array}$ & $\begin{array}{l}\text { Lesions }^{\mathrm{c}}(\%) \\
\text { MCGS }^{\mathrm{d}}\end{array}$ & $\begin{array}{l}\text { Degree of } \\
\text { infection }^{\mathrm{e}}\end{array}$ & $\begin{array}{l}\text { Recovery of acid fast } \\
\text { bacillif }(\%)\end{array}$ & $\begin{array}{l}\text { Weight } \\
\text { reduction }(\%)^{\mathrm{g}}\end{array}$ \\
\hline Control & 0 & 30 & 0 & 0 & None & $0 / 90(0 \%)$ & 0 \\
$\mathrm{~T}_{2}$ & 30 & 30 & 51 & 5.94 & Moderate & $41 / 90(45.55 \%)$ & $14.55 \pm 1.04^{\mathrm{a}}$ \\
$\mathrm{T}_{3}$ & 30 & 30 & 66 & 8.71 & Severe & $62 / 90(68.88 \%)$ & $17.39 \pm 1.16^{\mathrm{b}}$ \\
$\mathrm{T}_{4}$ & 30 & 30 & 78 & 8.89 & Severe & $76 / 90(84.44 \%)$ & $24.43 \pm 1.34^{\mathrm{c}}$ \\
\hline
\end{tabular}

${ }^{a}$ Number of fishes inoculated at the starting of experiment. Although the control group also had 30 fishes, but they were not inoculated with bacteria bof fish subjected to histopathological examination at the end of the 60 days of experimental trial.

'Percentage of overall pathological lesions observed in the inoculated fishes

${ }^{\mathrm{d}}$ Mean cumulative granuloma score (MCGS)

e Degree of infection according to the granuloma score mentioned in the MCGS ${ }^{\mathrm{d}}$ column.

fRecovery percentage of acid fast bacilli was measured as '(No. of bacterial samples isolated from tissue / No. of tissue samples examined) x 100'. Three kinds of tissues (skin, liver and head kidney) were examined.

gWeight reduction (\%) in L. rohita of each group due to exposure to M. fortuitum infection. Values (Mean \pm SE) over the bar with different superscripts $(\mathrm{a}, \mathrm{b}, \mathrm{c})$ showed significant difference $(\mathrm{p}<0.05)$.

Upregulation of blood glucose and cortisol levels after mycobacterial infection

At 30 and 60 days post-inoculation, stress biomarkers such as glucose and cortisol in blood were significantly increased. Untreated control group showed the lowest value of blood glucose and cortisol throughout the experimental period. Bacterial inoculation significantly increased the blood glucose level (Fig. 2a) and cortisol (Fig. 2b) levels on days 30 and 60 in group $T_{4}$. Groups $T_{2}$ and $\mathrm{T}_{3}$ showed lower concentrations of blood glucose and cortisol than group $\mathrm{T}_{4}$ on days 30 and 60 , but higher than that of control group.

Alteration in haematological parameters after mycobacterial infection

Bacterial infection significantly affected the haemoglobin $(\mathrm{Hb})$ and total erythrocyte count (TEC) with

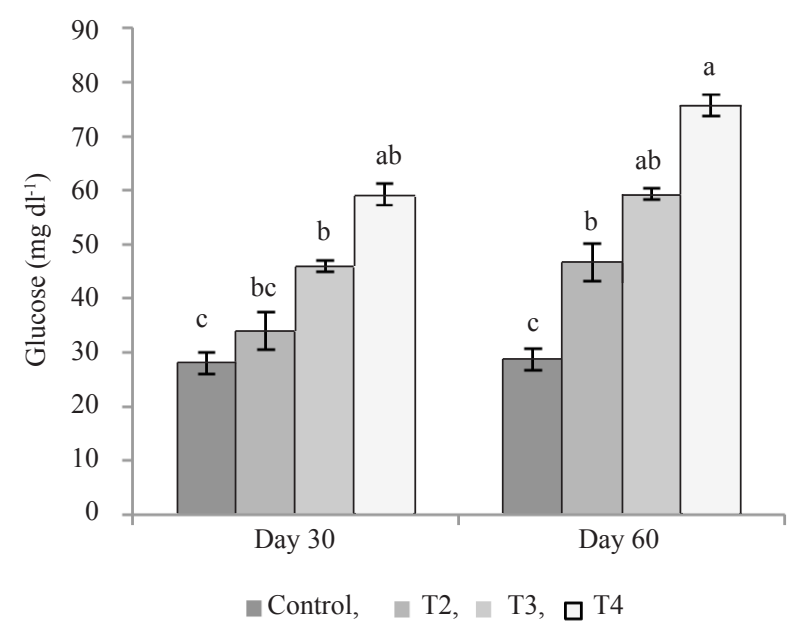

(a) highest values in control fishes and lowest in group $\mathrm{T}_{4}$ on days 30 and 60 (Fig. 3a, b). Group $\mathrm{T}_{2}$ and $\mathrm{T}_{3}$ also showed slight decrease on day 30 and significant decrease on day 60 in comparison to control. The total leukocyte count (TLC) was significantly higher in group $\mathrm{T}_{4}$ than control on day 30 to 60 . Group $\mathrm{T}_{2}$ and $\mathrm{T}_{3}$ also showed increase in TLC on day 30 and 60 (Fig. 3c).

Down regulation of plasma proteins due to mycobacterial infection

Stress due to pathogenic bacteria can negatively affect the serum protein levels (Ellis et al., 1981). Significant decrease was recorded in serum total protein in group $\mathrm{T}_{3}$ and $\mathrm{T}_{4}$ on day 30 followed by day 60 (Fig. 4a). Albumin level (Fig. 4b) was mildly lowered on day 30 and showed significant decrease on day 60 in all bacterial inoculated fishes. The globulin level showed mild reduction on day

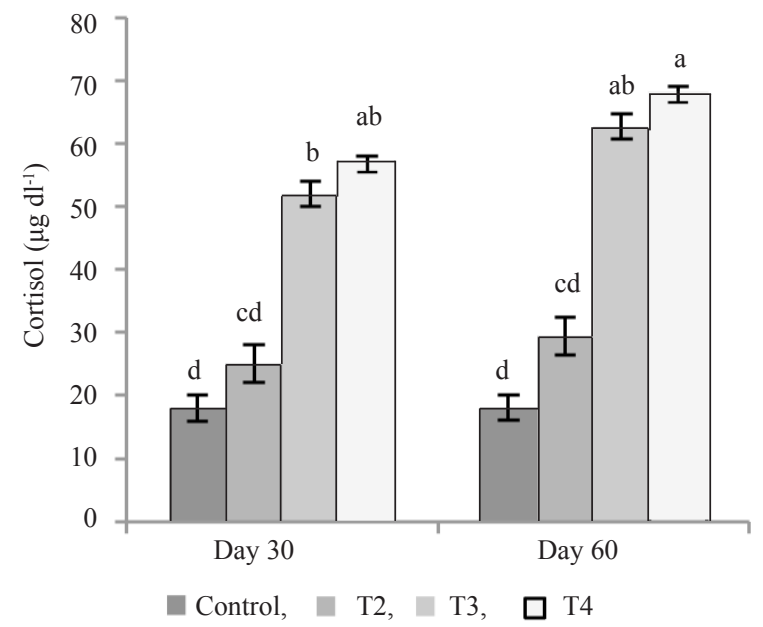

(b)

Fig. 2. Effects of M. fortuitum infection on (a) blood glucose levels and (b) serum cortisol levels (Mean \pm SE) in L. rohita. Different superscripts indicate significant difference $(\mathrm{p}<0.05)$ 


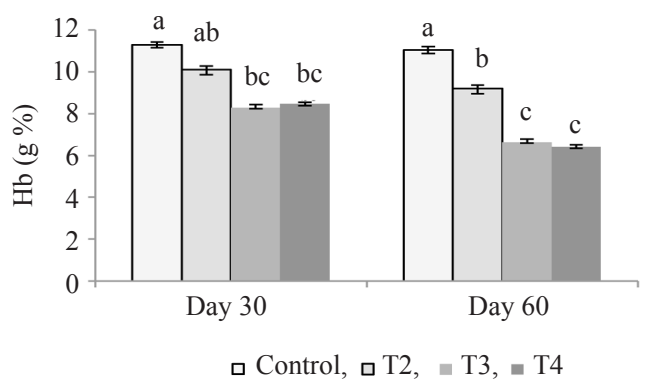

(a)

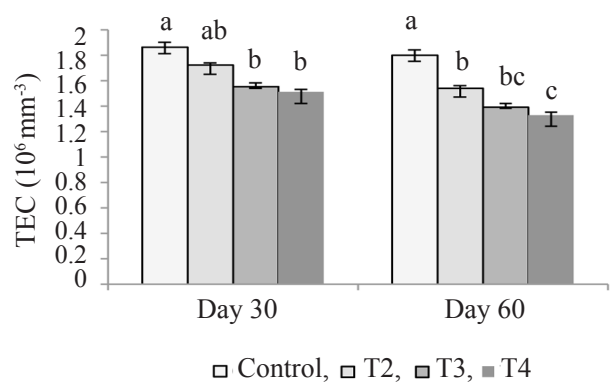

(b)

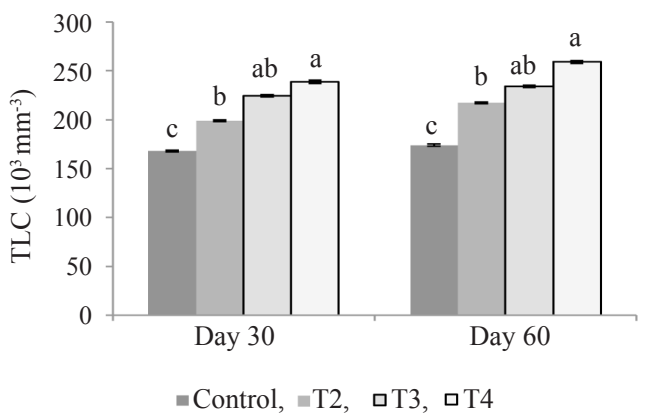

(c)

Fig. 3. Effects of M. fortuitum infection on (a) Hb, (b) TEC and (c) TLC levels (Mean \pm SE) in L. rohita. Different superscripts (a, b, c, d) show significant difference $(\mathrm{p}<0.05)$ between values

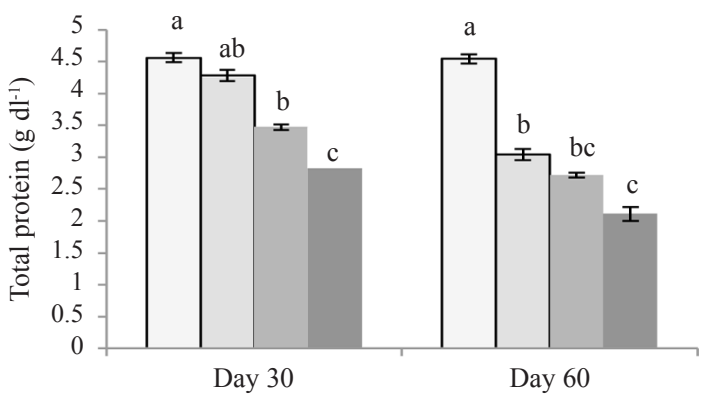

(a)

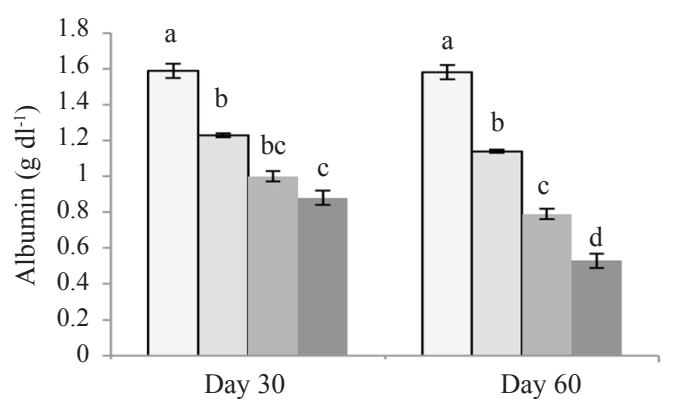

(b)

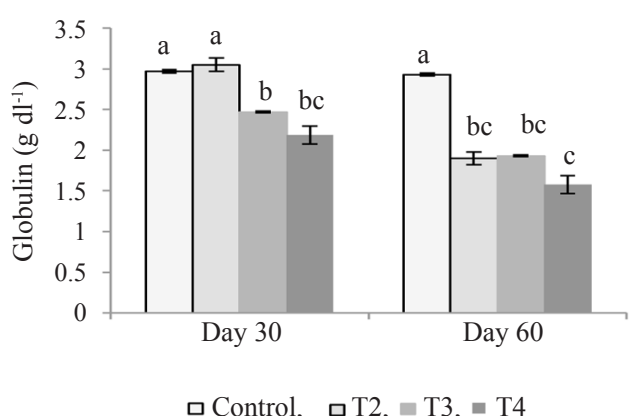

(c)

Fig. 4. Effects of M. fortuitum infection on (a) serum total protein, (b) albumin and (c) globulin levels (Mean \pm SE) in L. rohita. Different superscripts $(a, b, c, d)$ show significant difference $(p<0.05)$ between values 
30 but was significantly lowered at day 60 in bacteria inoculated fishes compared to control (Fig. 4c). As both serum albumin and globulin levels exhibited the same pattern of gradual decline with increase in bacterial dose, no significant changes were observed in the $\mathrm{A} / \mathrm{G}$ ratio.

Upregulation of enzyme activity after mycobacterial infection

There was no change in activities of ALT, AST, LDH and ALP in control fishes during experimental period. Group $\mathrm{T}_{4}$ showed significant $(\mathrm{p}<0.05)$ increase in serum ALT, ALP and LDH activities at days 30 and 60, while AST activity at day 60. Serum ALT activity in fish of group $\mathrm{T}_{2}$ and $\mathrm{T}_{3}$ remained unchanged at day 30 and was higher at day 60 in comparison with control (Fig. 5a). The AST activity in group $\mathrm{T}_{2}$ and $\mathrm{T}_{3}$ did not show any change at day 30 as compared to control, group $\mathrm{T}_{3}$ at day 60 showed higher levels than in control (Fig. 5b). Serum LDH remained unaltered in group $\mathrm{T}_{2}$ and mildly increased in group $T_{3}$ at day 30, but was higher in group $T_{2}$ and elevated in group $\mathrm{T}_{3}$ at day 60 as compared to control (Fig. $5 c)$. The ALP activity has shown an increasing pattern in group $\mathrm{T}_{2}$ followed by group $\mathrm{T}_{3}$ and finally highest in group $\mathrm{T}_{4}$ (Fig. 5d). Group $\mathrm{T}_{4}$ showed a significant increase in serum SOD activity at day 60 (Fig. 5e). Catalase activity displayed significant elevation in group $T_{3}$ and $T_{4}$ on day 30 and 60 as compared to control, but levels in fish of group $\mathrm{T}_{2}$ remained unchanged at day 30 which was found mildly elevated at day 60 (Fig. 5f).
Effect of M. fortuitum infection on heat shock protein gene expression

After 60 days post-inoculation, the expression level of mRNA of $h s p 60$ in liver tissue increased by 2 and 2.5 fold in group $\mathrm{T}_{3}$ and $\mathrm{T}_{4}$ respectively in comparison with control (Fig. 6a). Group $\mathrm{T}_{2}$ showed a slight increase of 1.5 fold in hsp60 level as compared to control (Fig. 6a). The hsp70 showed 1.5 and 2.5 fold increase in expression in group $\mathrm{T}_{2}$ and $\mathrm{T}_{3}$ respectively. The expression level of $h s p 70$ in group $\mathrm{T}_{4}$ was 5.5 fold higher $(\mathrm{p}<0.01)$ after 60 days postinoculation as compared to control (Fig. 6b). There was a gradual increase in $h s p 78$ gene expression with increase in bacterial concentration. The expression levels were increased by $1.5,3.5$ and 7.5 folds $(\mathrm{p}<0.01)$ in group $\mathrm{T}_{2}$, $\mathrm{T}_{3}$ and $\mathrm{T}_{4}$ respectively as compared to control (Fig. 6c). Significant increase $(\mathrm{p}<0.01)$ in expression level of $h s p 90$ (4.9 fold) gene was observed in group $\mathrm{T}_{4}$ than control group. Group $\mathrm{T}_{2}$ and $\mathrm{T}_{3}$ also showed up-regulation by 2.2 and 3.4 fold, following increase in bacterial concentration as compared to control (Fig. 6d). The expression level of hsp47 showed 1.2, 2.24 and $3.29(\mathrm{p}<0.05)$ fold changes in groups $\mathrm{T}_{2}, \mathrm{~T}_{3}$ and $\mathrm{T}_{4}$ respectively, compared to control (Fig. 6e).

Significant upregulation of hsp60, hsp 70 and $h s p 90$ following mycobacterial exposure were shown by Western Blot analysis (Fig. 7a-c). These results confirmed subsequent cellular stress by mycobacterial infection. Expression of $h s p 60$ and $h s p 70$ were significantly

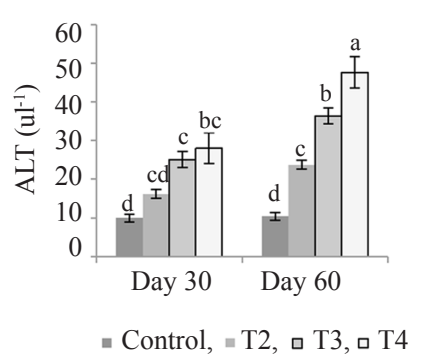

(a)

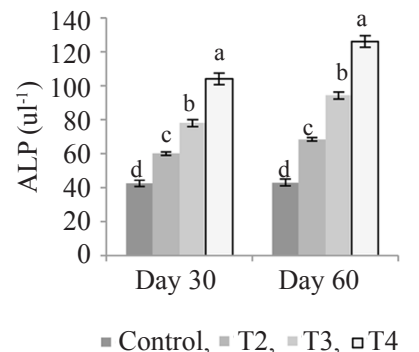

(d)

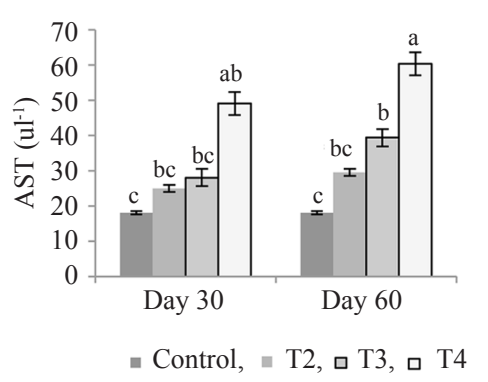

(b)

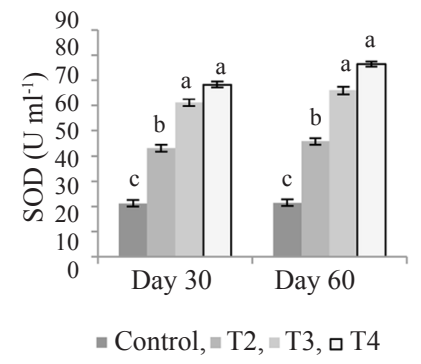

(e)

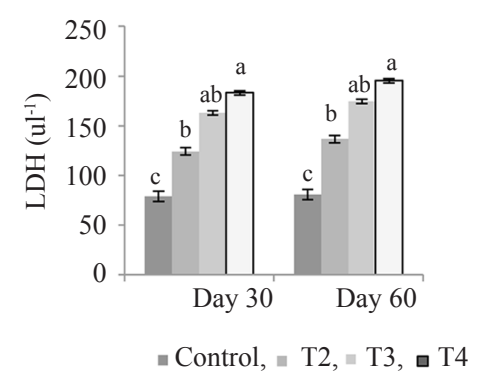

(c)

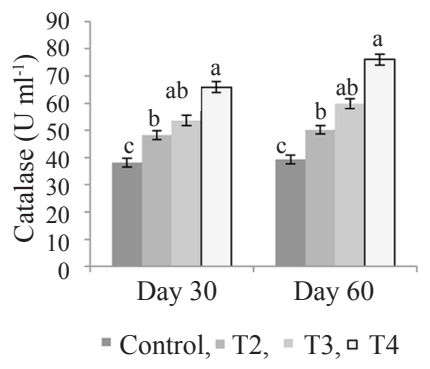

(f)

Fig. 5. Effects of M. fortuitum infection on serum (a) ALT, (b) AST, (c) LDH, (d) ALP, (e) SOD and (f) catalase levels (Mean \pm SE) in L. rohita. Different superscripts $(\mathrm{a}, \mathrm{b}, \mathrm{c}, \mathrm{d})$ show significant difference $(\mathrm{p}<0.05)$ between values 


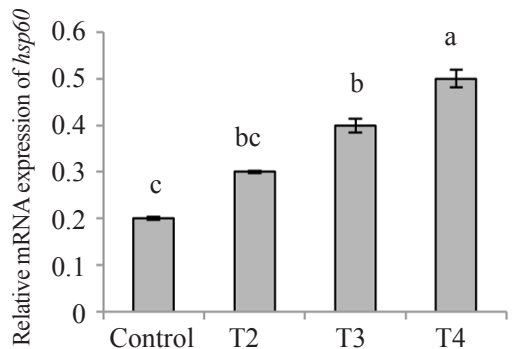

(a)

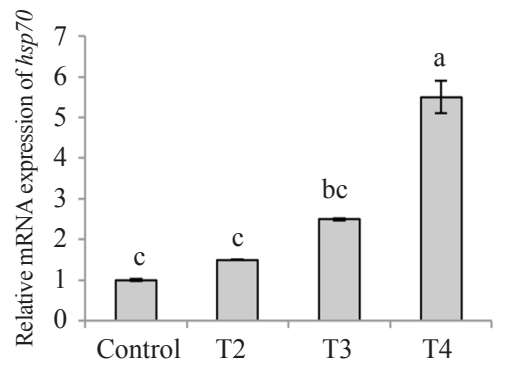

(b)

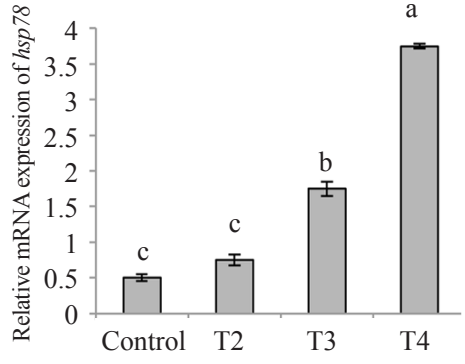

(c)

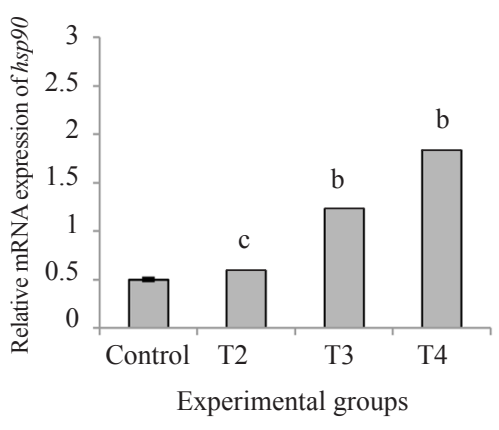

(d)

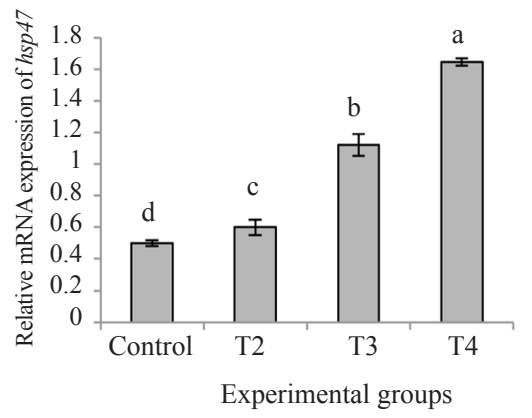

(e)

Fig. 6. Pattern in fold changes of (a) $h s p 60$, (b) $h s p 70$, (c) $h s p 78$, (d) $h s p 90$ and (e) $h s p 47$ gene expression in liver tissues of $L$. rohita in response to $M$. fortuitum infection. Data expressed as Mean $\pm \mathrm{SE}$ after normalising the value with Beta-actin (housekeeping gene). Different superscripts $(a, b, c, d)$ show significant difference $(p<0.05)$ between values

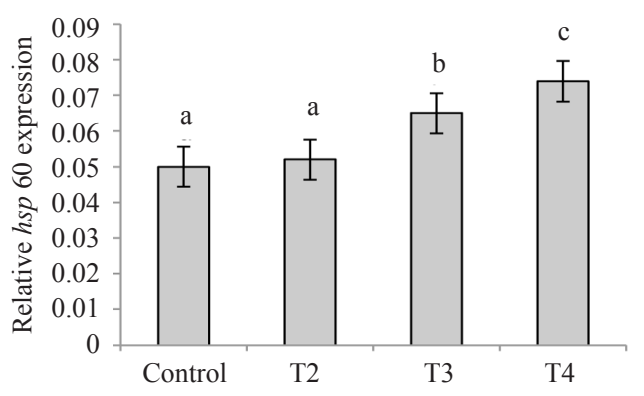

(a)

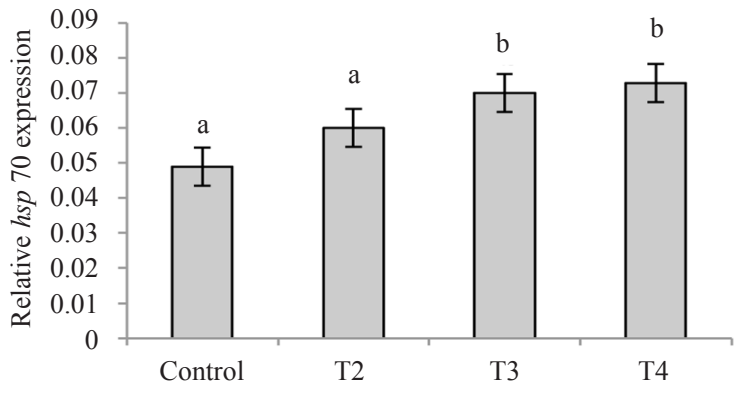

(b)

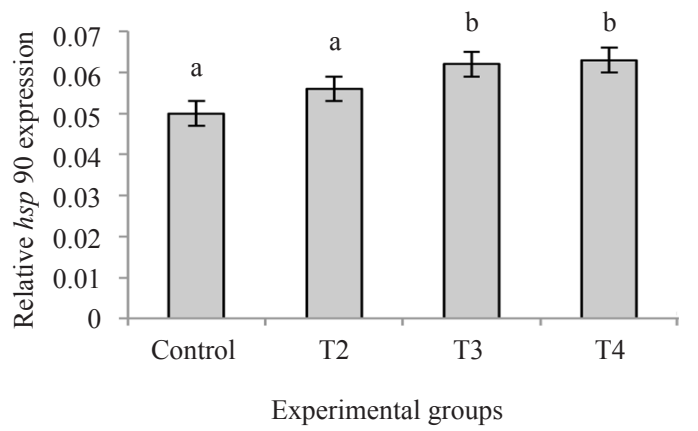

(c)

Fig. 7. Western blot analysis (1D) of $h s p 60, h s p 70$ and $h s p 90$ in liver tissues of $L$. rohita from different experimental groups. Relative protein expressions are shown as bar and analysed as Mean $\pm \mathrm{SE}$ after normalising with Beta-actin (housekeeping gene). Different superscripts $(a, b, c, d)$ show significant difference $(p<0.05)$ between values 
increased in group $\mathrm{T}_{4}$ compared to control. hsp 90 protein expression was getting higher with increased concentration of bacterial inoculum. However, researchers have hypothesised that the hsps are not direct components of non-specific immunity in lower to higher vertebrates but they are actively involved in proteome maintenance of cells to any kinds of stress conditions including bacterial inflammation (Banerjee et al., 2015).

\section{Discussion}

In the current study, we demonstrated the directly proportional relationship between serum glucose level and increasing dose of bacterial inoculation. The serum glucose level of laboratory fishes may be considered as an efficient marker to evaluate the stress response due to a variety of stress factors including bacterial inflammation and pathogenesis. A number of publications revealed that the elevation of serum glucose level is associated with different stressors including anthropogenic pollution (Manush et al., 2005), increased packing density during transportation (Chatterjee et al., 2006; Pakhira et al., 2015), harsh handling (Carey and McCormick, 1998) and infection due to pathogens (Pablos-Mendez et al., 1997). Any sort of stress factor elevates catecholamine (epinephrine) secretion which increases the rate of glycogenolysis pathway to enhance the blood glucose levels. Fishes of group $\mathrm{T}_{4}$ inoculated with $5 \times 10^{7} \mathrm{cfu} \mathrm{fish}^{-1}$ showed more than $50 \%$ infection rate than other inoculated groups. Increase in bacterial concentration showed a gradual elevation in serum glucose content in comparison to control groups. This may be due to stressor effects caused by bacterial infections. Higher blood glucose levels in the treatment groups were found as compared to control which explained the elevated stress levels in L. rohita caused by mycobacterial incursion.

Stress hormones like cortisol and epinephrine are released by fish in response to primary stressors induced by pathogenic infections. It tends to elevate the breakdown of glycogen as secondary responses to compensate the glucose demand during stress conditions (MartinezPorchas et al., 2009). Cortisol is considered as the key corticosteroid in fishes and circulating levels of this hormone in blood is commonly measured as an indicator of degree of stress induced in fishes (Pakhira et al., 2015). This study showed that, group $\mathrm{T}_{3}$ and $\mathrm{T}_{4}$ exhibited a noticeable elevation in serum cortisol levels after eight weeks that might have been augmented by mycobacterial stresses in fishes caused by that particular concentration of bacterial culture.

Atypical mycobacterium infection causes granulomatous damage in multiple tissues like hepatocytes, splenocytes and kidney parenchymal cells (Shukla et al.,
2013). Kidney and liver are the key organs for the synthesis of erythropoietin and any damage to these tissues can cause decrease in erythropoietin levels, which in turn decreases the erythrocyte production, reducing $\mathrm{Hb}$ levels. Therefore, decrease in TEC and $\mathrm{Hb}$ content may act as an indicator of respective organ damage. Decrease in $\mathrm{Hb}$ levels and TEC due to mycobacterial infection by Aeromonas sulmonicida has been reported in Atlantic salmon (Foda 1973). This reduction in $\mathrm{Hb}$ and erythrocytes might indicate elevated leukocytosis leading to erythrocytic anemia along with erythroblastosis in subsequent erythropoietic organs.

Leukocytes play a vital role in both innate and adaptive immunity of fish exposed to any kind of microbial pathogens, which is also considered as an important marker of immunity in all fishes. Mycobacterial infection causes increase in leukocytes representing the inflammatory response (Groote et al., 2006) which in turn expresses the immunogenic response along with stress. In this study, total leukocyte count was significantly higher in groups $T_{3}$ and $T_{4}$ than control, which may be due to immune-stress responses against mycobacterial invasion.

Serum proteins include different soluble proteins, albumin, globulin and various antibodies which are part of humoral immune system. Therefore, higher concentration of total serum protein represents the enhancement of nonspecific immune systems in fishes. This study showed that serum total protein, albumin and globulin contents decreased with increasing mycobacterial inoculation than the fishes of control group. A decrease in serum protein may be due to water imbalance in between intracellular and extracellular fluids and an increase can be caused by shifting of fluids from plasma to intracellular matrix (Milligan and Wood, 1982). Challenge with pathogenic $M$. fortuitum causes reduction in the serum protein levels, which could be attributed to leakage of serum proteins through the walls of blood vessels due to increased membrane permeability (Ellis et al., 1981). The amount of serum proteins, albumin and globulin was found to decrease in a similar manner due to mycobacterial infection, so that the albumin and globulin ratio remains unchanged after infection.

Results of the present study clearly indicated that mycobacterial exposure caused damage of the liver tissues and significantly increased ALT, AST, ALP and LDH levels. Damage in the liver cells led to the leaking out of liver enzymes into bloodstream, making their levels remarkably high in blood/serum. Therefore, the marked increase in serum levels of liver enzymes due to stress response may correlate with some previous findings (Pakhira et al., 2015). Tissue breakdown or damage causes the release of LDH in blood which in turn acts as a marker to indicate stress conditions. Our results highlighted 
a marked elevation in serum LDH level in relation to bacterial inflammation, which can be correlated with anaerobic catabolism of cortisol and damage in liver and muscle tissues. ALP mediates the phosphorylation process during membrane transport, therefore higher levels of ALP in blood may involve dephosphoryation of biomolecules that hampers the normal cellular mechanisms (Pakhira et al., 2015).

In vertebrates, the essential enzymes which acts as free radical scavengers are superoxide dismutase, catalase and glutathione peroxidase that are abundant in fishes in unstressed conditions (Di Giulio et al., 1993). But the amount of those enzymes increases two to three-fold to trigger the antioxidant defense pathway in response to oxidative stress mediated by reactive oxygen species such as superoxide anion $\left(\mathrm{O}_{2}^{-}\right)$, hydroxyl radicals $(\mathrm{OH}-)$, singlet oxygen $\left({ }^{1} \mathrm{O}_{2}\right)$ and hydrogen peroxide $\left(\mathrm{H}_{2} \mathrm{O}_{2}\right)$ (Fridovich et al., 1995). Changes in catalase activity was increased but not significant $(\mathrm{p}>0.05)$ among all treatment groups compared to control. However, it depends on the host pathogen interaction and cellular stress which further coincides with heat shock responses. hsps are highly expressed cellular proteins among all species including bacteria and higher eukaryotes, and are considered as molecular chaperones. These are the proteins which were named based on their molecular mass as hsp47, hsp60, hsp65 (65 kDa), hsp70 (68-70 kDa), hsp90 (85-90 kDa) and $h s p 110$. They are known to regulate the folding and stability of other cellular proteins under any kind of stress response. They are expressed at basal levels of $1-2 \%$ of all cellular proteins under controlled conditions. Adverse conditions such as environmental alteration, elevated temperature, chemicals and pathogenic infections can increase the expression of certain $h s p$ s to $4-6 \%$ of cellular proteins from the normal value to prevent the protein aggregation and misfolding (Cho et al., 1997; Purohit et al., 2014). These self $h s p$ s can further propagate the inflammatory processes and stimulate the $\mathrm{T}$ cells and antibodies which are previously induced by foreign pathogens. In higher organisms, their ability to interact with a number of proteins and molecules of immune system makes them usable in the treatment of several infectious diseases (Srivastava, 2002). This study clearly showed elevation in $h s p$ s expression due to atypical mycobacterial infections which are important stress and immunomodulatory markers in both humoral and cell mediated immune systems and the observations coincide with different previously documented literatures (Purohit et al., 2014).

This study revealed that $M$. fortuitum is a causative agent of fish tuberculosis characterised by haemorrhagic granulomas in L. rohita. Exposure to different doses of
M. fortuitum caused alteration in different physiological factors including non-specific immune responses and expression of several stress factors in L. rohita. Mycobacterial invasion was found to cause increase in liver aminotransaminase and $\mathrm{LDH}$, alteration in haematological factors, elevation in free and conjugate amino acid mobilisations, cortisol mediated glucose production to recompense the energy demand, increased production of reactive oxygen species along with upregulation of $h s p s$. The data we illustrated here might help to understand the stress indication related to mycobacteriosis in fishes, hostpathogen communication and development of new disease control aspects in aquaculture practices. Further studies are needed to screen mycobacterial disease pathogenicity in different species of fishes and possible remediation.

\section{Acknowledgements}

We are thankful to INSPIRE programme, Department of Science and Technology, Govt. of India; Department of Science and Technology and Biotechnology, Government of West Bengal, Department of Microbiology, West Bengal State University; Department of Physiology, West Bengal State University and Hon'ble Vice Chancellor, West Bengal State University.

\section{References}

Astrofsky, K. M., Schrenzel, M. D., Bullis, R. A., Smolowitz, R. M. and Fox, J. G. 2000. Diagnosis and management of a typical Mycobacterium spp. infections in established laboratory zebrafish (Brachydanio rerio) facilities. Comp. Med., 50: 666-672.

Banerjee, S., Mitra, T., Purohit, G. K., Mohanty, S. and Mohanty, B. P. 2015. Immunomodulatory effect of arsenic on cytokine and HSP gene expression in Labeo rohita fingerlings. Fish Shellfish Immunol., 44: 43-49. http://dx.doi.org/10.1016/j. fsi.2015.01.029.

Balouet, G. and Baudin, L. F. 1986. Granulomatous nodules in fish: An experimental assessment in rainbow trout, Salmo gairdneri Richardson and turbot, Scophthalmus maximus (L.). J. Fish Dis., 9: 417-429. https://doi. $\operatorname{org} / 10.1111 /$ j.1365-2761.1986.tb01035.x.

Bercovier, H. and Vincent, V. 2001. Mycobacterial infections in domestic and wild animals due to Mycobacterium marinum, M. fortuitum, M. chelonae, M. porcinum, M. farcinogenes, M. smegmatis, M. scrofulaceum, M. xenopi, M. kansasii, M. simiae and M. genavense. Sci. Tech. Rev., 20: 265-290. https://doi.org/10.20506/rst.20.1.1269 (In French).

Brown, T. H. 1985. The rapidly growing mycobacteriaMycobacterium fortuitum and Mycobacterium chelonei. Infect. Control, 6(7): 283-288. https://doi.org/10.1017/ s0195941700061762.

Carey, J. B. and McCormick, S. D. 1998. Atlantic salmon smolts are more responsive to an acute handling and confinement 
stress than parr. Aquaculture, 168: 237-253. https://doi. org/10.1016/S0044-8486(98)00352-4.

Chatterjee, N., Pal, A. K., Das, T., Manush, S. M., Sharma, K., Venkateshwarlu, G. and Mukherjee, S. C. 2006. Secondary stress response in Indian major carps L. rohita (Ham), Catla catla (Ham) and Cirrhinus mrigala (Ham) fry to increasing packing densities. Aquac. Res., 37(5): 472-476. https://doi.org/10.1111/j.1365-2109.2006.01469.x.

Cho, W., Cha, S., Do, J., Choi, J., Lee, J., Jeong, C., Cho, K., Choi, W., Kang, H., Kim, H. and Park, J. 1997. A novel 90-kDa stress protein induced in fish cells by fish rhabdovirus infection. Biochem. Biophys. Res. Commun., 233(2): 316-319. https://doi.org/10.1006/bbrc.1997.6387.

Collins, C. H., Grange, J. M. and Yates, M. D. 1984. Mycobacteria in water. J. Appl. Bacteriol., 57(2): 193-211. https://doi. org/10.1111/j.1365-2672.1984.tb01384.x.

Di Giulio, R. T., Habig, C. and Gallagher, E. P. 1993. Effects of black rock harbor sediments on indices of biotransformation, oxidative stress and DNA integrity in channel catfish. Aquat. Toxicol., 26: 1-22. https://doi. org/10.1016/0166-445X(93)90002-I.

Doumas, B. T. and Biggs, H. G. 1972. Determination of serum albumin. In: Cooper, G. A. (Ed.), Standard methods of clinical chemistry, vol. 7. Academic Press, New York, USA, p. $175-188$

Ellis, A. E., Hastings, T. S. and Munro, A. L. S. 1981. The role of Aeromonas salmonicida extracellular products in the pathology of furunculosis. J. Fish Dis., 4: 41-52. https:// doi.org/10.1111/j.1365-2761.1981.tb01108.x.

Foda, A. 1973. Changes in hematocrit and haemoglobin in Atlantic salmon (Salmo salar) as a result of furunculosis disease. J. Fish. Res. Board Can., 30(3): 467-468. https:// doi.org/10.1139/f73-081.

Fox, L. E., Kunkle, G. A., Homer, B. L., Manella, C. and Thompson. J. P. 1995. Disseminated subcutaneous Mycobacterium fortuitum infection in a dog. J. Am. Vet. Med. Ass., 206(1): 53-55.

Fridovich, I. 1995. Superoxide radical and superoxide dismutases. Annu. Rev. Biochem., 64(1): 97-112. https:// doi.org/10.1146/annurev.bi.64.070195.000525.

Gail, L. W. and David, H. W. 1996. Detection of infection or infectious agents by use of cytologic and histologic stains. Clin. Microbiol. Rev., 9(3): 382-404. https://doi. org/10.1128/CMR.9.3.382-404.1996.

Groote, M. A. D. and Huitt, G. 2006. Infections due to rapidly growing Mycobacteria. Clin. Infect. Dis., 42(12): 17561763. https://doi.org/10.1086/504381.

Heckert, R. A., Elankumaran, S., Milani, A. and Baya, A. 2001. Detection of a new Mycobacterium species in wild striped bass in the Chesapeake Bay. J. Clin. Microbiol., 39(2): 710-715. https://doi.org/10.1128/JCM.39.2.710-715.2001.
Kakkar, V., Meister-Broekema, M., Minoia, M., Carra, S. and Kampinga, H. H. 2014. Barcoding heat shock proteins to human diseases: Looking beyond the heat response. Disease Models and Mechanisms, 7: 421-434. https://doi. org/10.1242/dmm.014563.

Katoch, V. M. 2004. Infections due to non-tuberculous mycobacteria (NTM). Indian J. Med. Res., 120(4): 290-304.

Manush, S. M., Pal, A. K., Das, T. and Mukherjee, S. C. 2005. Dietary high protein and vitamin $\mathrm{C}$ influences in mitigating stress due to chelate claw ablation in Macrobrachium rosenbergii males. Comp. Biochem. Physiol. Part A, Mol. Integr. Physiol., 142(1): 10-18. https://doi.org/10.1016/j. cbpb.2005.07.004.

Martínez-Porchas, M., Martínez-Ciordova, L. R. and RamosEnriquez, R. 2009. Cortisol and glucose: Reliable indicators of fish stress? Pan-American Journal of Aquaic Science, 4(2): 158-178.

Marzouk, M. S. M., Essa, M. A. A., El-seedy, F. R., Kenawy, A. M. and EL-Gawad, D. M. A. 2009. Epizootiological and histopathological studies on mycobacteriosis in some ornamental fishes. Global Veterinaria, 3(2): 137-143.

Milligan, C. L. and Wood, C. M. 1982. Disturbances in hematology, fluid volume distribution and cardiovascular function associated with low environmental $\mathrm{pH}$ in the rainbow trout, Salmo gairdneri. J. Exp. Biol., 99: 397-415.

Mohanty, B. P., Banerjee, S., Bhattacharjee, S., Mitra, T., Purohit, G. K. and Sharma, A. P. 2013. Muscle proteomics of the Indian major carp catla (Catla catla, Hamilton). J. Proteomics Bioinformatics, 6(11): 252-263. https://doi. org/10.4172/jpb.1000288.

Mohanty, B. P., Bhattacharjee, S., Mondai, K. and Das, M. K. 2010. HSP70 expression profiles in white muscles of riverine catfish Rita rita show promise as biomarker for pollution monitoring in tropical rivers. Natl. Acad. Sci. Lett., 33(5-6): 177-182.

Noga, E. J., Wright, J. F. and Pasarell, L. 1990. Some unusual features of mycobacteriosis in the cichlid fish Oreochromis mossambicus. J. Comp. Pathol., 102(3): 335-344. https:// doi.org/10.1016/s0021-9975 (08)80022-9.

Oser 1944. Hawk's physiological chemistry, $14^{\text {th }}$ edn. McGraw Hill Publications, New York, USA, p. 1054-1055.

Pablos-Mendez, A., Blustein, J. and Knirsch, C. A. 1997. The role of diabetes mellitus in the higher prevalence of tuberculosis among Hispanics. Am. J. Public Health, 87(4): 574-579. https://doi.org/10.2105/ajph.87.4.574.

Pakhira, C., Nagesh, T. S., Abraham, T. J., Dash, G. and Behera, S. 2015. Stress responses in rohu, L. rohita transported at different densities. Aquac. Rep., 2: 39-45. https://doi. org/10.1016/j.aqrep.2015.06.002.

Parashar, D., Chauhan, D. S., Sharma, V. D., Chauhan, A., Chauhan, S. V. S. and Katoch, V. M. 2004. Optimisation of procedures for isolation of environmental mycobacteria 
from soil and water samples of north India. Appl. Env. Microbiol., 70(6): 3751-3753. https://doi.org/10.1128/ AEM.70.6.3751-3753.2004.

Prasad, U., Satanand, P., Prasad, P. D. and Amitabh, P. 2012. Length weight relationship and condition factor of L. rohita in Govindgarh Lake, Rewa (M.P.). Indian J. Res., 1: 185-187.

Prearo, M., Zanoni, R. G., Campo, Dall'Orto, B., Pavoletti, E., Florio, D., Penati, V. and Ghittinio, C. 2004. Mycobacterioses: Emerging pathologies in aquarium fish. Vet. Res. Commun., 28: 31-317. https://oi.org/10.1023/ B:VERC.0000045435.19522.af.

Purohit, G. K., Mahanty, A., Suar, M., Sharma, A. P., Mohanty, B. P. and Mohanty, S. 2014. Investigating hsp gene expression in liver of Channa striatus under heat stress for understanding the upper thermal acclimation. Biomed. Res. Int., 9: 1-10. https://doi.org/10.1155/2014/381719.

Reimschuessel, R., Bennett, R. O. and Lipsky, M. M. 1992. A classification system for histological lesions. J. Aquat. Anim. Health, 4: 135-143. https://doi.org/10.1577/15488667(1992)004<0135:CACSFH > 2.3.CO;2.

Reinhold, J. G. 1953. Manual determination of serum total protein, albumin and globulin fractions by Biuret method. In: Reiner, M. (Ed.), Standard method of clinical chemistry Academic Press, New York, USA, 88 pp.

Rhodes, M. W., Kator, H., Kaattari, I., Gauthier, D., Vogelbein, W. and Ottinger, C. A. 2004. Isolation and characterisation of Mycobacteria from striped bass Morone saxatilis from the Chesapeake Bay. Dis. Aquat. Org., 61(1-2): 41-51. https:// doi.org/10.3354/dao061041.

Sanders, G. E. and Swaim, L. E. 2001. Atypical piscine mycobacteriosis in Japanese medaka (Oryzias latipes). Comp. Med., 51(2): 171-175.

Saito, H. and Tasaka, H. 1969. Comparison of the pathogenicity for mice of Mycobacterium fortuitum and Mycobacterium abscessus. J. Bacteriol., 99(3): 851-855. https://doi. org/10.1128/JB.99.3.851-855.1969.

Shukla, S., Sharma, R. and Shukla, S. K. 2013. Detection and identification of globally distributed mycobacterial fish pathogens in some ornamental fish in India. Folia
Microbiologica, 58(5): 429-436. https://doi.org/10.1007/ s12223-013-0225-y.

Smole, S. C., McAleese, F., Ngampasutadol, J., Von Reyn, C. F. and Arbeit, R. D. 2002. Clinical and epidemiological correlate of genotypes within the Mycobacterium avium complex defined by restriction and sequence analysis of hsp65. J. Clin. Microbiol., 40(9): 3374-3380. https://doi org/10.1128/JCM.40.9.3374-3380.2002.

Srivastava, P. 2002. Role of heat-shock proteins in innate and adaptive immunity. Nat. Rev. Immunol., 2(3): 185-194. https://doi.org/10.1038/nri749.

Sun, Y-Z., Yang, H-L., Ma, R-L. and Lin, W-Y. 2010. Probiotic applications of two dominant gut Bacillus strains with antagonistic activity improved the growth performance and immune responses of grouper Epinephelus coioides. Fish Shellfish Immunol., 29(5): 803-809. https://doi. org/10.1016/j.fsi.2010.07.018.

Takahara, S., Hamilton, B. H., Nell, J. V., Kobra, T. Y., Oguna, Y. and Ni-shimura, E. T. 1960. Hypocatalesemia: A new genesis carrier state. J. Clin. Investig., 39(4): 610-619. https://doi.org/10.1172/JCI104075.

Talaat, A. M., Reimschuessel, R., Wasserman, S. S. and Trucksis, M. 1998. Goldfish, Carassius auratus, a novel animal model for the study of Mycobacterium marinum pathogenesis. Infect. Immun., 66(6): 2938-2942. https:// doi.org/10.1128/IAI.66.6.2938-2942.1998.

Talaat, A. M., Reimschuessel, R., Kane, A. S. and T rucksis, M. 1999. Pathogenicity of Mycobacterium fortuitum and Mycobacterium smegmatis to goldfish, Carassius auratus. Vet. Microbiol., 66(2): 151-164. https://doi.org/10.1016/ s0378-1135(99)00002-4.

Wilkinson, G. T., Kelly, W. R. and O'Boyle, D. 1978. Cutaneous granulomas associated with Mycobacterium fortuitum in a cat. J. Small Anim. Pract., 19(1-12): 357-362. https://doi. org/10.1111/j.1748-5827.1978.tb05505.x.

Zhu, L., Nie, L., Zhu, G., Xiang, L. and Shao, J. 2013. Advances in research of fish immune relevant genes: A comparative overview of innate and adaptive immunity in teleosts. Dev. Comp. Immunol., 39(1-2): 39-62. https://doi.org/10.1016/j. dci.2012.04.001. 